\title{
The Components of Islamic Entrepreneurship Pattern Based on Religious Teachings
}

\author{
Mohammad Bagher Babaee Talatappeh ${ }^{1} \&$ Mohammad Reza Tavalaee $^{2}$ \\ ${ }^{1}$ University of Imam Hossein, Tehran, Iran. \\ ${ }^{2} \mathrm{PhD}$ Student of Entrepreneurship, Qazvin Branch, Islamic Azad University of, Qazvin, Iran \\ Correspondence: Mohammad Bagher Babaee Talatappeh, University of Imam Hossein, Tehran, Iran. E-mail: \\ mbbabaee@ihu.ac.ir
}

Received: February 12, 2016

Accepted: March 23, 2016

Online Published: March 27, 2016

doi:10.5539/mas.v10n6p37

URL: http://dx.doi.org/10.5539/mas.v10n6p37

\begin{abstract}
Today, many scholars in the domain of economy and entrepreneurship indicated to entrepreneurship as a development engine such as Shompiter. They tried to use this leverage for development and welfare of their countries.

The current paper studies the Islamic entrepreneurship conceptual pattern according to Islamic studies and based on the four-aspect system including entrepreneurship, personal, organizational, social and moral. As moral and religious values determine the social and devotional value, they also focus on efforts for developing the society. In Quran, God settled efforts for human being.

The present paper studies how innovation as a fundamental concept will produce the Islamic entrepreneurship structure beside Islamic moral and values.

The methodology used in this study includes theoretical and citation studies through using Islamic reliable resources. The findings were gained based on the Islamic teaching in Quran and behavior of saints.
\end{abstract}

Keywords: entrepreneurship, innovation, islamic entrepreneurship, islamic values

\section{Methodology}

Theoretical scholarism and documentary methods were used in this research. In this regard, all valid documents related to Islamic teachings of entrepreneurship and merciful Quran approach, prophet (pbuh) tradition and innocents, and other valid references have been used which have relevance to entrepreneurship to determine it.

Therefore, this article was conducted according to previous articles and researches, analysis the mentioned references, combination of points of view, and entrepreneurship field models.

\section{Definition of Entrepreneurship according to Islam Transcendental Point of View}

Entrepreneurship lexically is rooted from French term of "ENTREPRENDRE" which means commitment. According to definition of terminology and texture of entrepreneurship, entrepreneur is who accept, manage, and organize an economic activity. It can be stated that actually, there has been no comprehensive and acceptable definition by all authorities. In other words, various and varied definitions have been proposed about entrepreneurship equal to number of authorities. Some define entrepreneur as the main driving force in competitive economic development and engine to extend product and quality which role is innovation or making new combinations from performance and productions and know "innovation" and "evolving creativity" as the main characteristics of entrepreneur. According to others, entrepreneur is a person who brings significant relationship between scarce references, managerial capabilities, and human resources. Yet, in common view of authorities, entrepreneur is one of the most important factors of economic development. They believe that entrepreneurs are thoughtful and inventive managers make new opportunities to make economic value with creativity, risk taking, intelligence, thought of vision breadth. They are able to revolute by innovations and make a failing company to profitable one or change dissatisfaction to satisfaction. (Morrison,2000)

Since Islamic religion, which mentions to all hidden and obvious angles of human life, is complete religion, it is possible to obtain all material surviving guidance of course to the extent of our understanding by investigating it. Maybe, there is beautiful definition about entrepreneurship by prophet. 
In Islamic culture, human is creature who enters to world after the world creation steps as though world is incomplete without it, so God gave the status of Khalifa of God and assigned attempt as human growth and felicity. (Babaei Talatapeh, 2015)

\section{Types of Entrepreneurship:}

Entrepreneurship is a process in which new thought and idea in combination with collection of resources by process of business, that is involved with financial, social, and prestige, provide a new product for market. Various classifications of entrepreneurship were conducted by various researchers some of which are mentioned in the following:

Importance based on characteristic, social, and behavioral fields have identified 2 types of entrepreneurships:

Artisan entrepreneurs 2-opportunistic entrepreneurs .

\section{Environment:}

Common managerial schools point of view from any paradigms is made by one united origin. The basis of this origin is a systematic point of view. This origin states that no organization can work in vacuum. All organizations are limited into an environment. What more important is that organizations deal with this environment both want or not want. Effectiveness of organization on environment depends on organization size, activity, and other variables. Sometimes, this effectiveness is intangible and negligible. A multinational company with high technology significantly influences on environment, while organization, in any kind, is impressed by its environment, because environment supplies their needs, buy their outputs, and above all, provide cultural and valuable condition for their activities. If environment is not adapted with their entrepreneurial activities, makes the biggest obstacle for entrepreneurship, while a supportive environment appraises employees to continue business opportunities. According to Kolveried \& Obloj, perceiving a supportive and full resources environment is vital in entrepreneurs' decision making to follow opportunities. Abetti believes that entrepreneurs should select a field of activity with all key elements or are actively be developing (Lin et al., 2006: 171-172). According to Richard O. Mason, agreement with changing environment is probably the most important factor in determination success or failure of s free business system. (Kuratko and Hajts, 2004: 240)

Environment includes various aspects. One of so important aspects is cultural and value aspect. Value and cultural aspect directly influence on entrepreneurial activities and indirectly by mediation of another factor. In the rest, these aspects are described.

\section{Cultural Environment:}

Culture is important issue in entrepreneurship, because it indicates people attitude toward entrepreneurship.

In each period, specific entrepreneurship models are shaped based on society needs. There are extensive variations of entrepreneurship conception in international level each one reinforces or supports entrepreneurial behavior differently. According to Joynt and Warner, if a culture has pro-entrepreneurship values, it will be incubator for entrepreneurship. It is true vice versa. In societies than entrepreneurship is disturbed with overcharge, speculation, offense, and crime, it shows that it is not perceived well. Its examples are Chicago in 1930s and number of transferring economics from Eastern Europe in 1990s. Although, many authorities such as Bateman know negativity of this step as inevitable step of transferring development, it may promote and register an anti-entrepreneurship behavior.

\section{Islam Culture and Entrepreneurship:}

Here, the relationship between culture and entrepreneurship is measured by Hofstede index. According to results of Hofstede, predisposing and incentive cultures of entrepreneurship are pluralism, having low power, high risk taking level, and long-term intention. Now, it should be clarified that how much these criterions are adaptable with Islamic regulations and teachings. In Islam religion, team work, people-orientation, consultation, and social life of humans are significantly emphasized. Nowhere in this religion, individual-orientation, seclusion, staying away of people even to worship God are not suggested. Although, worship is nice and obligatory activity, human shouldn't spend all his life time on worship and staying away from people.

One of Islam attempt and purposes has been establishing equality and justice among all people. Wealth, status, specialty, etc. have never been priority of people than others. As God said: the prior subject according to God view is the most faithful one. It is noticeable that human virtue and integrity will be clear for God, so people shouldn't measure others virtue according to their point of view, but they should have similar behaviors to others'.

According to entrepreneurs' authorities, taken risk by entrepreneurs is a calculated and logical risk. In other 
worlds, entrepreneurs are not seeking for lottery. Trust conception has very close relationship with logical risk. Although, trust conception is wrong in public beliefs, its main conception states that every one should try hard to get to his/her purposes and not be afraid of problems and non-pleasance and trust on God. Actually, trust in Islam means accepting logical risks and hoping to God for success.

Islam teachings are important factor in people intention to long-term purposes and programs. In Islam, people shouldn't try just for their own purposes to get it as soon as possible, but they should try to give services to different ranks of society. The discussion of "actions with later results" proposed in Islam makes a lot of motivations for people to plant for far future and even for the next generation.

As it was explained, Islam teachings not only agree with entrepreneurship success, but also support it greatly. As a result, it can be claimed that Islam is principally entrepreneurial culture itself and provides proper condition for entrepreneurship development.

Now, according to Islam rich culture, how it is possible to provide necessary needs and protect integration of cultural system using elements of other cultures especially western culture. Islam principals haven't disagreed with accepting constitutional elements of other cultures at all and even emphasized significantly. Islam accepts each cultural element effective in discovering realities or utilization. Similarly, science equally can be referred, as it is emphasized in holly book on investigation a lot. Prophet (pbuh) also said: search for science even it is in China (Saeidi Kia, 2006: 251). Therefore, in culture of Islam bright religion, no disagreement is about accepting other cultures elements if they are constitutional.

\section{Valuable Environment:}

In each society, values form people behaviors in society. Values indicate which action or even thought is correct and each one is incorrect. Dominant ideology on a society determines values of that society.

Ideology is a system of vivid and clarified judgments and ideas that are usually organized to describe, justify and interpret situation of a group or society. This system suggests and offers certain and specific routing for social reaction of that group or society. Therefore, according to the mentioned definition, ideology inside culture is considered as a fully integrated, coordinated, and organized collection of perceptions and provides ideas so it can be called a system. (Note 1).

Studies show that some social principles promote and some others prevents from entrepreneurship.

\section{Islamic Values and Entrepreneurship:}

Today attempts of many organizational managers and psychologists are focused on motivating self-confidence in human, because they know self-confidence as an important driving force for human attempt. Islam religion stabilizes this sense in human by emphasizing on person action. Human fate is made by himself according to Islam religion. It means action is all and human happiness is tiled to action. Merciful Quran says: there is nothing for human except his attempts. This teaching is one of the biggest one for life of a society. If a society knows that it should determine its fate, it depends on its attempts and understands that nothing changes condition for its benefit and this is a big factor for dynamisms and attempt. As Will Durant says: no religion except Islam hasn't invite its followers to power. (Saeidi Kia, 2006: 255)

However, how we have been in practice? Such eat religion is weak and abandoned today. Many Islamic prosperities pass awful poverty, while many of these Islamic Muslim countries have a lot of God blessing resources and natural resources. So what is the root of the problem? According to a wise scientific, Iqbal Lahuri, the defect is in Muslims thoughts; otherwise, values and regulations of this religion support work, attempt, and getting power. Wrong perception and incorrect views about values weakens entrepreneurship.

Our perception from this religion is fate-orientation. In this regard, not only human fate is in his hand, but also many attempts are illegal which considered as interruption in God action. This attitude will not be only a deriving fore for attempt, but also a great obstacle against them.

\section{Trust}

It was significantly emphasized on Islam in trust. Some Muslims believe on trust as as should assign tasks to God and shouldn't just hope to attempt. Actually, they trust on God for fate of every thing that they don't want to try or see that harder than their abilities, but trust has dynamic conception in Islam. It means whenever Quran wants to motivate humans to do an action and make them free of anxiety, states trust on God. Philosophy of trust on God in an environment full of hesitation means that by trust on God we should try our best instead of yielding or withdrawing. Believe on trust in its accurate meaning helps to entrepreneurship growth, because as it was mentioned, entrepreneurship guarantees risk taking and belief in trust helps everyone accepting dangers by trust 
on God and and passes vague paths by tact. (Saeidi Kia, 2006: 255-256)

\section{Piety and secularism}

In public belief, abstinent is told to one who depends on the minimum of the world and contentment in expression. In this point of view, people try to release the world and its belongings are called abstinent. It means wealth and saving money is naturally considered rejected and unpleasant. However, it should be stated that Islam disagrees with every wealth or illegal wealth. According to Islam, every wealth that bothers others or its obtaining resource and spending ways harmful are considered unpleasant; otherwise, Islam doesn't disagree with wealth and saving money, but also support is significantly. Teachings of this bright religion have never emphasized on isolation. Undoubtedly, wise maker didn't create such blessings unmeaning. The final purpose of all is providing service to human.

Abstinence in Islam means entrepreneurship ethics. It means trying for personal benefit, if not harm to others, is emphasized in Islam. So Islam doesn't fight with getting wealth, but it is prevention from illegal or harmful wealth for society and considering entrepreneurship ethics.

What can be inferred from merciful Quran is that obtaining healthy and proper life is tied to utilizing holly teachings, thought, positive, wise, and useful activity. General guidelines and main way of getting to favorable life is maturating some parts of potential talents and operate them, because material ad world life doesn't have full capacity of maturating all human talents.

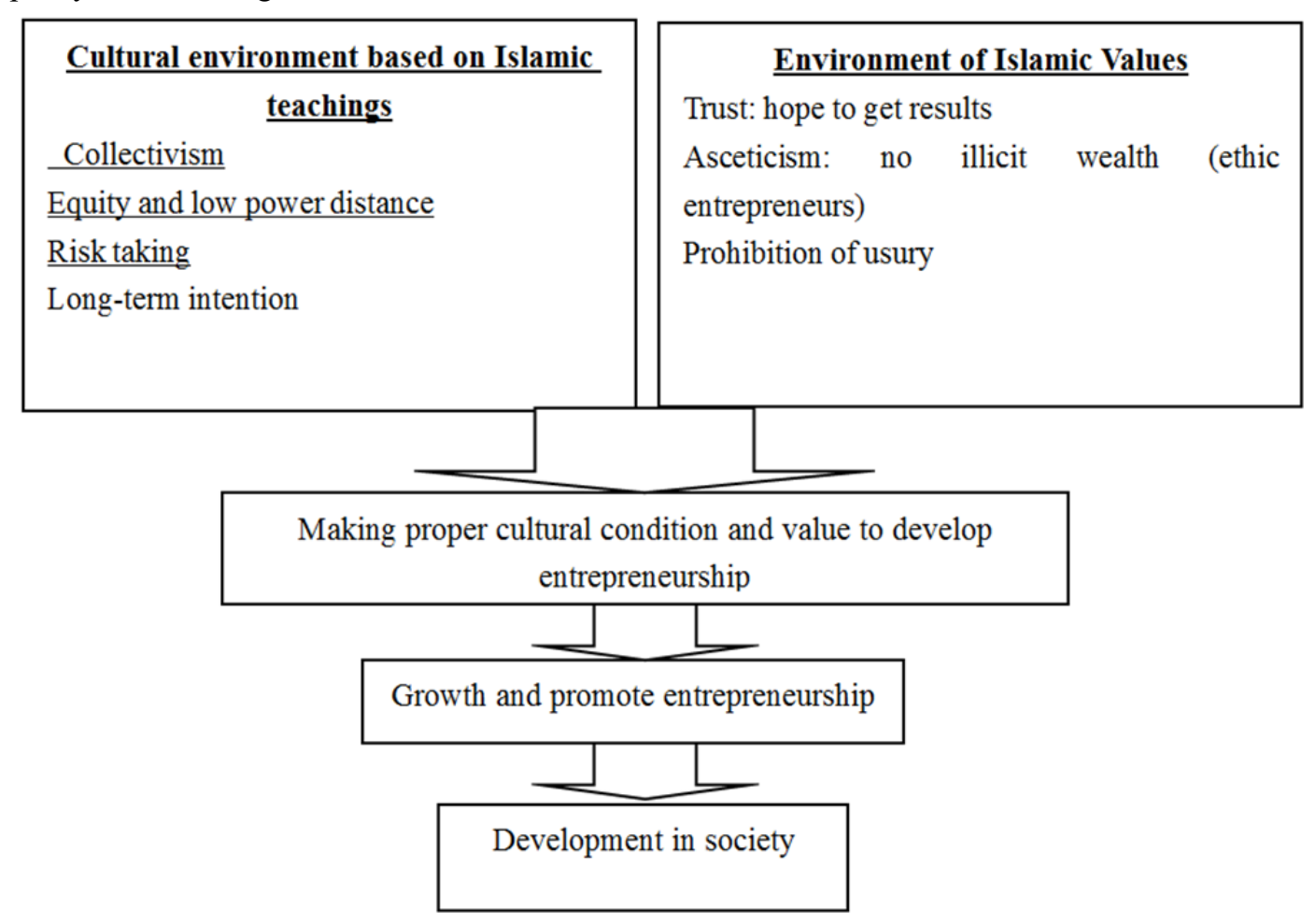

Figure 1. Role of Islamic culture and values in development of entrepreneurship (Salarzehi, Hashemi, 2013)

In value system and innocent speeches particularly in prophet (pbuh) look along with Quran verses and Revelation economic affairs and entrepreneurship are attributed to the great part of human life.

- Entrepreneurship Approaches in Islamic Teachings

- Entrepreneurship in Merciful Quran

Quran is the most principal resource of Islam and vector of all values working on faith and recognition (Jafari, 1997: 50). Quran verses about attempts and working role in life is so various that explicitly it can be stated that Quran teachings are related to attempt and generally to entrepreneurship.

\subsection{First Group: Work, Result of Human Life}

Verses that know work as result of human life include: 
"And that man hath only that for which bee make the effort, (An-Najm: 39) means: nothing won't stay for human except its attempts and his attempt will be seen definitely"

\subsection{Second Group: Relationship between Faith and Practice in Getting Result}

Some verses conditions faith result to practice and conditions practice result to faith as following:

1) Lo! Those who believe (in that which is revealed unto thee, Muhammad), and who are Jews, and Christians, and Sabaeans, whoever believed in Allah and the Last day and doeth right surely their reward is with their Lord, and there shall no fear come upon them neither shall they grieve. (Al-Baqarah: 62)

2) "Whosever doeth right, whether male or female, and is a believer, him verily we shall quicken with good life, and we shall pay them a recompense in proportion to be the best of what they used to do." (An-Nahl: 97)

There are more than 60 verses in Quran that faith is corresponded to practice and getting to each one is conditioned to getting another. (Jafari, 1997: 2-23)

\subsection{Fourth Group: Relationship between Working and Attempt with Growth Steps and Its Degrees}

This group includes verse introducing criteria and growth degrees such as Al-Anaam: 132)

This group increase magnificence of attempt and doesn't introduce recognition as the only criterion of human growth. According to other verses introducing faith and recognition as growth criterion, such as (Mojadeleh: 11), it is clarified that growth and maturity has 3 elements: recognition, faith, and practice. (Jafari Eisa Fallah: 31 )

\subsection{Fifth Group: Human Creation Field, Serious and Final Attempt}

Some Quranic verses introduce human creation field as serious and final attempt such as:

A) "We verily have created man in an atmosphere" (Al-Balad: 4)

B) "Thou, verily, O man, art working toward they Lord a work which thou wilt meet (in his presence)." (Al-Inshiqaq: 6)

\section{Ethics of Muslim Entrepreneurs}

Entrepreneurs have various characteristics that some are instinctive and some are obtainable. Each person with any talent has ability of changing to an entrepreneur and creative person by attempt. Since "little work with vision and though will be great and big work with negligence is little", one of the most important feature of entrepreneur is his/her vision and tact. A very vivid notion yet very important is hidden in the mentioned sentence. Entrepreneurs work tactfully and pass long ways in short path by doing apparently small work intelligently and get high benefits for themselves and their society. The difference between intelligent entrepreneurs and other activity is such as comparing released energy from Uranium and burning several tones of coals. A little movement and turn toward entrepreneurship make evolution improving economic structure.

Being futuristic, having landscape, hard attempt, and perseverance are bright gems of entrepreneurs which smooth dark path to bright and problems heights. Changing to creative person with noble ideas or in other words, changing a person to the one with potential entrepreneurship is such as putting in a path leading to activating designs, fertilizing idea tree to the fruitful tree by operationalizing and attempt. Unconsciously, business increases a person knowledge. Therefore, entrepreneur becomes wiser and more educated, because business increases on wisdom. Of course, entrepreneurship is with opportunity seeking and ambitiousness. It is policy which makes him/her more determined in creativity path to complete it. This policy has another resource, too that is hidden in getting personal satisfaction in being useful for others and liberalism and greatly refuse from telling lie and usury, and seek for rights, take working easy, be fair, tolerant, and kind. Entrepreneurs get enough information and skill before starting a business such as learning how to start a business and its steps, how to do team work and learn communicative skills, and always try to recognize financial issues, how market performed, management principles, all insurances, economic macro and micro issues, working law, lawful affairs, and so on. They should either have ability of developing management, business growth, findings new competitive methods, protecting situation in market and how to find new markets or ask people with such features to cooperate. It is far than entrepreneurs have all features, so they should employ such people and cooperate with them. Then entrepreneurs should interest in team work and divide tasks and grow participation and team work culture among themselves. In Ash-Shu'ara' Surah, Noble God said he put his blessing for subjects "who worship, do koshers and pray, and do their jobs by consultation with others, tolerate, have valuable virtues, and determined." Entrepreneurs know their subordinates power and don't compare them with themselves. Therefore, assign job to them regarding to their powers; otherwise, help them. 
Although, entrepreneurship is not instinctive feature and can grow and be learnt, it is God blessing for human that should use its benefit for society poor people.

It is serious notice for entrepreneurs in God speech: "when a person is harmed, he prays me for their problems, then I give him/her blessings: this blessing is given to her/him for my tact, but this is their experiment tool, but they don't know."

\section{Conclusion}

Islam with all-dimensional look to various aspects of human life and its emphasis on attempt and reacting value in life value context, gets far from the solely material and economic world view by purpose of providing service to God subjects and satisfying God. This research suggests its conception in macro analysis framework and elements of cyclical pattern by investigating various references and extraction key conceptions related to Islamic entrepreneurship.

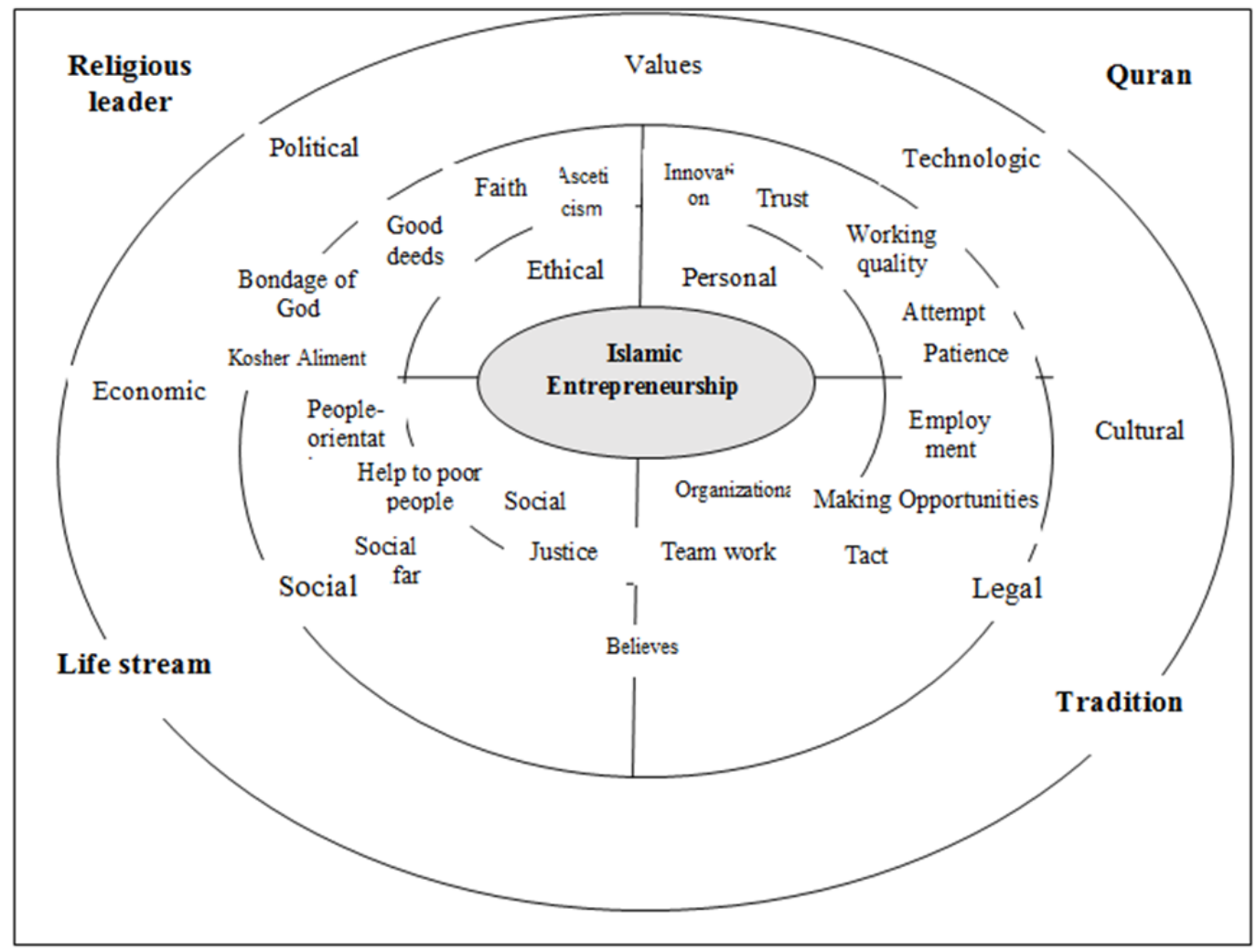

Figure 2. Islamic Entrepreneurship pattern

\section{References}

Babaei, T., \& Mohammad, B. (2015). Management and entrepreneurship in Islamic values, Pouya Andish pub.

Fallah, M. F. (2010), attempt and work by Islamic scholars, Tehran: publication, Islamic research centers of Face and Voice.

Jafari, M. T. (1997). Translation and interpretation of Nahj, seventh pub. Of fourth volume, Tehran: Islamic culture promotion office

Kuratko, D. F., \& Hajetse, R. M. (2002). Contemporary attitude on entrepreneurship, translated by Ebrahim Amel Mehrabi, Mashhad, Ferdowsi Mashhad University Pub., First express.

Lin, B.W., Li, P. C., \& Chen, J. S. (2006). Social capital, capabilities, and entrepreneurial strategies: a study of Taiwanese high-tech new ventures, Technological Forecasting \& Social Change, No.73, pp.168-181

Morrison, A. (2000). Entrepreneurship: what triggers it? International Journal of Entrepreneurial Behavior \& research, vol.6, no.2, pp.59-71, MCB University Press

Saeidi, K. M. (2006). Entrepreneurship bases and principles. Tehran, Kiya Pub. Fourth pub. 
Salarzehi, H. A., Hashemi, J. (2014). values and Islamic culture role in promoting entrepreneurship and development

Notes.

Note 1. www.daneshnameh.roshd.ir/mavara/mavara-index.php

\section{Copyrights}

Copyright for this article is retained by the author(s), with first publication rights granted to the journal.

This is an open-access article distributed under the terms and conditions of the Creative Commons Attribution license (http://creativecommons.org/licenses/by/3.0/). 